\title{
THE IMPACT OF CAREER DEVELOPMENT AND WORKLOAD TOWARD EMPLOYEE JOB SATISFACTION AT PT ASKRINDO JAKARTA
}

\author{
Widya Parimita \\ Fakultas Ekonomi Universitas Negeri Jakarta \\ Email: widya_parimita@yahoo.com \\ Wisnu Satrio Pambudi \\ Fakultas Ekonomi Universitas Negeri Jakarta \\ Email: wisnusatriopambudi@gmail.com \\ Hania Aminah \\ Fakultas Ekonomi Universitas Negeri Jakarta \\ Email: hania@unj.ac.id
}

\begin{abstract}
The purpose of this study are 1) determining the description of the workload, career development and job satisfaction in PT Askrindo, 2) testing empirically the effect of career development on job satisfaction at PT Askrindo, 3) testing empirically the effect of workload on job satisfaction at PT Askrindo, 4) empirically examining the influence of career development and workloads together on job satisfaction at PT Askrindo. Research conducted on 84 employees of PT Askrindo. The data collection technique using a survey method that is distributed questionnaires and processed by SPSS. This study used a descriptive analysis and explenatory. Results of regression showed that there is a significant positive effect between career development and job satisfaction, and there is a significant negative effect between workload and job satisfaction. Career development and work load together affect the job satisfaction of employees.
\end{abstract}

Keywords: Job satisfaction, career development, workload. 


\section{PENDAHULUAN}

\section{Latar Belakang Masalah}

Setiap organisasi yang dibentuk tentu terdapat suatu tujuan yang ingin dicapai. Salah satu faktor penting yang mendukung dalam pencapaian tujuan tersebut adalah sumber daya manusia dalam organisasi itu sendiri. Sumber daya manusia di dalam suatu organisasi perlu untuk dikelola yang kemudian diarahkan untuk mecapai tujuan organisasi.

Salah satu masalah yang dihadapi oleh perusahaan dalam mencapai tujuan organisasi adalah penanganan yang rendah terhadap kualitas sumber daya manusia. Dalam mencapai hasil yang diinginkan tentu dibutuhkan sikap kerja yang positif dari karyawan. Untuk itu organisasi harus menyadari dan memperhatikan faktor-faktor yang berpengaruh terhadap sikap kerja karyawan demi tujuan organisasi itu sendiri.

Kepuasan kerja dapat diartikan sebagai pandangan karyawan yang menyenangkan atau tidak menyenangkan terhadap pekerjaan yang dilakukan. Kepuasan kerja memiliki berbagai dampak terhadap pegawai. Pegawai yang memiliki kepuasan kerja yang baik dicerminkan dengan adanya prestasi kerja dan disiplin kerja yang baik. Sedangkan kepuasan kerja yang rendah akan berdampak terhadap ketidakhadiran, produktivitas dan keluarnya pegawai dari suatu organisasi.

Tingkat ketidakpuasan kerja yang terjadi dapat dilihat dari tingkat kehadiran karyawan atau kemangkiran karyawan dan keterlambatan masuk karyawan yang diduga terjadi karena rutinitas pekerjaan karyawan itu sendiri. Berikut ini adalah data absensi pada PT. Askrindo: 
Tabel 1. Data Absensi Karyawan PT Askrindo

Periode Agustus 2015 - Desember 2016

\begin{tabular}{clccc}
\hline Bulan & Keterangan & Ketidakhadiran & $\begin{array}{c}\text { Total Jumlah } \\
\text { Karyawan }\end{array}$ & Persentase \\
\hline Agustus & Tidak hadir & 26 & 110 & $23,6 \%$ \\
\hline September & Tidak hadir & 30 & 110 & $27,2 \%$ \\
\hline Oktober & Tidak hadir & 33 & 110 & $30 \%$ \\
\hline November & Tidak hadir & 28 & 110 & $25,4 \%$ \\
\hline Desember & Tidak hadir & 30 & 104 & $28,8 \%$ \\
\hline Januari & Tidak hadir & 32 & 104 & $30,7 \%$ \\
\hline Februari & Tidka hadir & 33 & 107 & $30,8 \%$ \\
\hline Maret & Tidak hadir & 37 & 107 & $34,5 \%$ \\
\hline April & Tidak hadir & 30 & 107 & $28 \%$ \\
\hline Sum: & & PT Ask
\end{tabular}

Sumber: Data PT Askrindo 2015-2016

Berdasarkan data diatas, data absensi karyawan yang peneliti gunakan adalah data ketidakhadiran tanpa alasan yang jelas atau sering disebut alpha pada bulan Agustus 2015 hingga April 2016. Hal ini mengindikasikan kepuasan kerja karyawan yang rendah pada PT. Askrindo. Karyawan yang tingkat kepuasannya rendah ditunjukan dengan ketidakhadiran yang rendah, mangkir kerja atau terlambat masuk kerja.

Adapun faktor yang mempengaruhi kepuasan kerja adalah pengembangan karier. Hasil riset peneliti melalui wawancara dan kuisioner, menunjukan bahwa untuk karyawan biasa rasanya sulit untuk mendapat jabatan yang lebih tinggi karena pengembangan karier di PT Askrindo pelaksanaannya belum maksimal. Persepsi karyawan terhadap pengembangan karier pada perusahaan yang seakanakan tidak ada perkembangan, karena pengembangan karier seorang karyawan sebagian besar dan lebih diprioritaskan diukur oleh faktor senioritas. Jadi, karyawan-karyawan junior harus bersabar menunggu para senior dan menghabiskan waktunya lebih lama untuk mencapai karier yang lebih baik.

Rotasi karyawan juga jarang dilakukan perusahaan sehingga karyawan yang kurang senang dengan posisi pekerjaan yang sekarang tidak bisa berpindah posisi yang danggap cocok dengan kemampuannya.Faktor lainnya yang 
mempengaruhi kepuasan kerja adalah beban kerja. Dari hasil wawancara yang telah dilakukan oleh peneliti kepada karyawan, peneliti memperoleh informasi bahwa karyawan PT Askrindo memiliki beban kerja yang tinggi dan dituntut untuk bekerja memenuhi target yang telah ditetapkan. Jajaran komisaris PT Askrindo memberikan beban kerja dengan sistem target yang tinggi. Ditambah dengan kenaikan target setiap tahunnya.

Karyawan juga harus melakukan lembur apabila tuntutan target yang telah ditetapkan tidak tercapai. Karyawan juga merasa beban kerja yang diterima oleh mereka kadang tidak adil. Mereka yang bekerja pada divisi marketing dan divisi klaim dan suborgasi merasa bahwa beban kerja mereka lebih tinggi daripada divisi lainnya yang ada di perusahaan. Padahal pada divisi yang lain juga memiliki jumlah tenaga kerja yang lebih banyak daripada divisi marketing atau divisi suborgasi. Berikut hasil keusioner pra riset di PT Askrindo:

Tabel. 2 Kuesioner pra riset Di PT. Askrindo

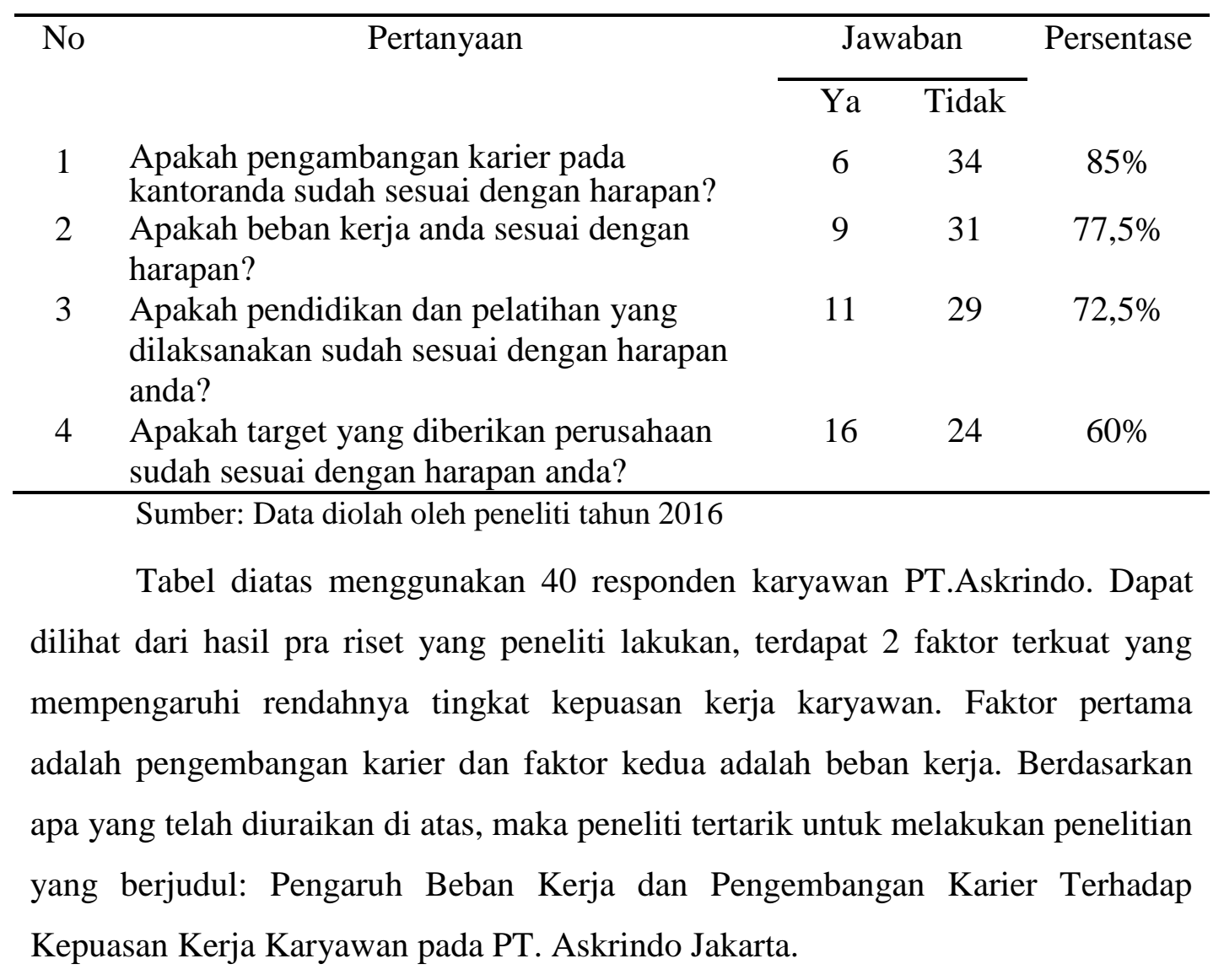




\section{Rumusan Masalah}

1. Bagaimana deskripsi pengembangan karier, beban kerja dan kepuasan kerja pada PT. Askrindo?

2. Apakah pengembangan karier berpengaruh terhadap kepuasan kerja pada PT. Askrindo?

3. Apakah beban kerja berpengaruh terhadap kepuasan kerja pada PT. Askrindo?

4. Apakah pengembangan karier dan beban kerja berpengaruh secara bersama-sama terhadap kepuasan kerja pada PT.Askrindo?

\section{Tujuan Penelitian}

1. Untuk mengetahui deksripsi pengembangan karier, beban kerja dan kepuasan kerja pada PT. Askrindo

2. Untuk menguji secara empiris pengaruh pengembangan karier terhadap kepuasan kerja pada PT. Askrindo

3. Untuk menguji secara empiris pengaruh beban kerja terhadap kepuasan kerja pada PT. Askrindo

4. Untuk menguji secara empiris pengaruh pengembangan karier dan beban kerja secara bersama-sama terhadap kepuasan kerja pada PT. Askrindo

\section{KAJIAN TEORETIK}

\section{Kepuasan Kerja}

Kepuasan kerja menurut Wexley dan Yukl (2012:327) adalah "generalisasi sikap-sikap terhadap pekerjaannya." Bermacam-macam sikap seseorang terhadap pekerjaannya mencerminkan hal yang menyenangkan dan tidak menyenangkan dalam pekerjaannya serta harapan-harapannya terhadap kejadian masa depan.

Pendapat lain yaitu menurut Robbins dan Judge (2013:131) yang memberikan definisi kepuasan kerja sebagai "perasaan positif tentang pekerjaan sebagai hasil evaluasi dari karakteristiknya." Pekerjaan memerlukan interaksi dengan rekan sekerja dan atasan, mengikuti aturan dan kebijakan organisasional, 
memenuhi standar kinerja, hidup dengan kondisi kerja kurang ideal, dan semacamnya.

Menurut Luthans (2012:283), kepuasan kerja adalah hasil dari persepsi karyawan mengenai seberapa baik pekerjaan mereka memberikan hal yang dinilai penting".

Berdasarkan pendapat ahli di atas dapat disimpulkan bahwa kepuasan kerja adalah perasaan menyenangkan yang dihasilkan dari persepsi karyawan mengenai seberapa penting pekerjaan mereka.

\section{Pengembangan Karier}

Pengembangan karier menurut Mangkunegara (2009:77) adalah “aktivitas kepegawaian yang membantu pegawai-pegawai merencanakan karier masa depan mereka di perusahaan agar perusahaan dan pegawai yang bersangkutan dapat mengembangkan diri secara maksimum."

Pendapat lain yaitu menurut Hasibuan (2012:69) mendefinisikan penembangan karier sebagai "suatu usaha untuk meningkatkan kemampuan teknis, teoritis, konseptual, dan moral karyawan sesuai dengan kebutuhan pekerjaan/jabatan melalui pendidikan dan latihan." Pendidikan meningkatkan kemampuan teoritis, konseptual, dan moral karyawan, sedangkan pelatihan bertujuan untuk meningkatkan keterampilan teknis tentang pekerjaan karyawan.

Marwansyah (2012:224) mengemukakan bahwa "sarana pengembangan karier meliputi keterampilan, pendidikan dan pengalaman serta teknik-teknik modifikasi dan perbaikan perilaku, yang memberikan nilai tambah sehingga memungkinkan seseorang untuk bekerja lebih baik."

Berdasarkan pendapat ahli di atas dapat disimpulkan bahwa pengembangan karier adalah kegiatan dan proses yang berkelanjutan oleh perusahaan untuk pegawai dalam meningkatkan kemampuan untuk mengisi jabatan perusahaan pada masa mendatang

\section{Beban Kerja}

Menurut Hart and Staveland (2010:16) beban kerja adalah "hubungan yang dirasakan antara jumlah kemampuan mental dalam pemrosesan dan jumlah yang dibutuhkan untuk mengerjakan suatu tugas." 
Sedangkan menurut Meshkati (2014:7) "beban kerja adalah suatu perbedaan atara kapasitas atau kemampuan pekerja dengan tuntuan pekerjaan yang harus dihadapi."

Sehingga dapat disimpulkan menurut pendapat ahli di atas bahwa beban kerja adalah tuntutan pekerjaan yang harus diselesaikan oleh karyawan dalam suatu waktu tertentu.

\section{Model Penelitian}

\section{Gambar 1. Model Penelitian}

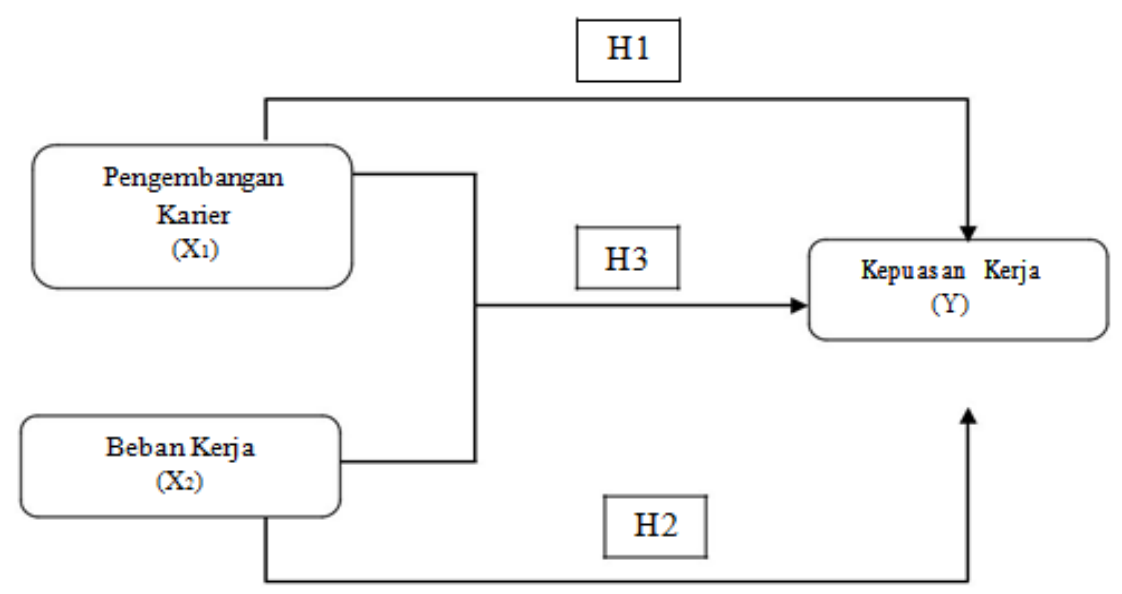

Sumber: Data diolah peneliti, 2016

\section{Hipotesis}

Berdasarkan kajian teori dan model di atas, maka hipotesis pada penelitian ini adalah:

\section{Hipotesis 1}

$\mathrm{H}_{\mathrm{o}}$ : Pengembangan karier tidak berpengaruh terhadap kepuasan kerja pada PT. Askrindo.

$\mathrm{Ha}_{\mathrm{a}}$ : Pengembangan karier berpengaruh terhadap kepuasan kerja pada PT. Askrindo.

Hipotesis 2

Ho : Beban kerja tidak bepengaruh terhadap kepuasan kerjapada PT. Askrindo.

$\mathrm{Ha}_{\mathrm{a}}$ : Beban kerja berpengaruh terhadap kepuasan kerja pada PT. Askrindo. 
Hipotesis 3

Ho : Pengembangan karier dan beban kerja secara bersama-sama tidak berpengaruh terhadap kepuasan kerja pada PT. Askrindo.

$\mathrm{Ha}$ : Pengembangan karier dan beban kerja secara bersama-sama berpengaruh terhadap kepuasan kerja pada PT. Askrindo.

\section{METODE PENELITIAN}

Penelitian ini menggunakan metode penelitian deskriptif dan explanatory. Data yang digunakan dalam penelitian ini berasal dari dataprimer yang didapatkan melalui wawancara dan kuesioner, sedangkan data sekunder didapatkan melalui data karyawan yang diperoleh peneliti melalui PT Askrindo. Metode pengambilan sampel menggunakan teknik probabilitysampling. Jumlah sampel yang digunakan dalam penelitian ini sebanyak 84responden.

\section{HASIL DAN PEMBAHASAN}

\section{Uji Instrumen}

\section{Uji Validitas}

Validitas dapat diartikan sebagai suatu karakteristik ukuran terkait dengan tingkat pengukuran sebuah kuesioner dalam mengukur secara benar apa yang diinginkan peneliti untuk diukur. Kriteria pengujian validitas adalah jika nilai rhitung $>$ rtabel, maka instrumen valid. Sebaliknya jika nilai rhitung $<$ rtabel, maka instrumen tidak valid dan harus dihilangkan atau diganti.

Uji validitas dilakukan dengan menyebar kuesioner pada sampel diluar sampel yang digunakan dalam penelitian namun memiliki kemirimpan kriteria. Hasil uji validitas dapat dilihat pada tabel 3 di bawah ini:

Tabel 3. Hasil Uji Validitas

\begin{tabular}{lccc}
\hline \multicolumn{1}{c}{ Variabel } & $\begin{array}{c}\text { Item Sebelum } \\
\text { Diuji }\end{array}$ & $\begin{array}{c}\text { Item Tidak } \\
\text { Valid }\end{array}$ & Item Valid \\
\hline Kepuasan Kerja & $\mathbf{1 0}$ & $\mathbf{0}$ & $\mathbf{1 0}$ \\
\hline Pengembangan Karier & $\mathbf{9}$ & $\mathbf{0}$ & $\mathbf{9}$ \\
\hline Beban Kerja & $\mathbf{9}$ & $\mathbf{0}$ & $\mathbf{9}$ \\
\hline
\end{tabular}

Sumber : Data diolah peneliti,2016 
Berdasarkan Tabel 3. hasil uji validitas yang dilakukan pada variabel kepuasan kerja, pengembangan karier dan beban kerja tidak mempunyai item pernyataan yang tidak valid, karena rhitung tiap instrumennya lebih besar dari rtabel. Sehingga dapat disimpulkan bahwa seluruh butir pernyataan dalam variabel tersebut valid karena seluruh instrumen telah memenuhi syarat yaitu nilai rhitung> rtabel 0.361 .

\section{Uji Reliabilitas}

Uji reliabilitas digunakan untuk mengetahui derajat ketepatan, ketelitian, atau keakuratan yang ditunjukkan oleh instrumen pengukuran. Kriteria pengujian reliabilitas adalah jika nilai cronbach's alpha> 0,6, maka instrumen reliabel. Sebaliknya jika nilai cronbach's alpha< 0,6 maka instrumen tidak reliabel.

Hasil uji reliabilitas untuk masing-masing variabel dapat dilihat pada Tabel 4. berikut :

Tabel 4. Hasil Uji Reliabilitas

\begin{tabular}{lcc}
\hline \multicolumn{1}{c}{ Variabel } & Cronbach's Alpha & Keterangan \\
\hline Pengembangan Karier $\left(\mathrm{X}_{1}\right)$ & 0.925 & Reliabel \\
\hline Beban Kerja $\left(\mathrm{X}_{2}\right)$ & 0.918 & Reliabel \\
\hline Kepuasan Kerja $(\mathrm{Y})$ & 0.836 & Reliabel \\
\hline Sumber: data diolah peneliti, 2016 & &
\end{tabular}

Pada Tabel 4. terlihat nilai Cronbach's Alpha> 0.6; untuk variabel pengembangan karier, beban kerja dan kepuasan kerja secara berurutan adalah $0.925,0.918,0.836$. Instrumen dari ketiga variabel tersebut dinyatakan reliabel.

\section{Analisis Deskriptif}

Deskripsi data adalah hasil pengolahan data mentah variabel penelitian yang dimaksudkan untuk memberikan gambaran umum mengenai penyebaran dan distribusi data. Data yang didapatkan merupakan hasil penelitian melalui kuesioner yang disebarkan pada sampel 84 karyawan PT Askrindo. 
Hasil analisis deskriptif untuk masing-masing variabel dapat dilihat pada Tabel 5. berikut :

Tabel 5. Hasil Analisis Deskriptif

\begin{tabular}{lccc}
\hline & Kepuasan Kerja & Pengembangan Karier & Beban Kerja \\
\hline Sangat Setuju & $21.3 \%$ & $25.4 \%$ & $31.1 \%$ \\
\hline Setuju & $24.1 \%$ & $16.2 \%$ & $33 \%$ \\
\hline Tidak Setuju & $47.6 \%$ & $48.6 \%$ & $21.6 \%$ \\
\hline Sangat Tidak Setuju & $7.1 \%$ & $9.7 \%$ & $14.3 \%$ \\
\hline Sumber : Data diolah peneliti, 2016 & &
\end{tabular}

Pada Tabel 5 dapat dilihat bahwa jawaban yang diberikan responden menggambarkan setiap variabel. Pada variabel kepuasan kerja, jawaban yang dipilih responden didominasi oleh kategori tidak setuju dengan persentase sebesar 47.6\%. Dapat disimpulkan bahwa kepuasan kerja karyawan PT Askrindo termasuk ke dalam kategori rendah.

Pada variabel pengembangan karier, jawaban yang dipilih responden didominasi oleh kategori tidak setuju dengan persentase sebesar $48.6 \%$. Dapat disimpulkan bahwa pengembangan karier yang diterapkan perusahaan dirasakan belum efektif oleh karyawan.

Sedangkan pada variabel beban kerja, jawaban yang dipilih responden didominasi oleh kategori setuju dengan persentase sebesar 33\%, dan sangat setuju sebesar 31.3\%. Dapat disimpulkan bahwa beban kerja karyawan PT Askrindo termasuk ke dalam kategori tinggi.

\section{Uji Asumsi Klasik}

\section{Uji Normalitas}

Uji normalitas dilakukan untuk mengetahui apakah data yang diambil berasal dari populasi yang berdistribusi normal atau tidak. Uji ini menggunakan uji Kolmogrov-Smirnov dan dinyatakan berdistribusi normal jika signifikansi lebih besar dari 0.05 . 
Tabel 6. Hasil Uji Normalitas

One-Sample Kolmogorov-Smirnov Test

\begin{tabular}{|c|c|c|c|c|}
\hline & & KepuasanKerja & PengembanganKarir & BebanKerja \\
\hline $\mathrm{N}$ & & 84 & 84 & $\overline{84}$ \\
\hline \multirow[t]{2}{*}{ Normal Parameters ${ }^{\mathrm{a}, \mathrm{b}}$} & Mean & 26.06 & 23.15 & 25.44 \\
\hline & Std. Deviation & 5.235 & 5.358 & 5.447 \\
\hline Most Extreme & Absolute & .054 & .048 & .053 \\
\hline \multirow[t]{2}{*}{ Differences } & Positive & .047 & .048 & .048 \\
\hline & Negative & -.054 & -.036 & -.053 \\
\hline \multicolumn{2}{|l|}{ Kolmogorov-Smirnov Z } & .491 & .437 & .487 \\
\hline \multicolumn{2}{|l|}{ Asymp. Sig. (2-tailed) } & .970 & .991 & .972 \\
\hline
\end{tabular}

a. Test distribution is Normal.

b. Calculated from data.

Sumber : Perhitungan SPSS 22, 2016

Berdasarkan hasil analisis uji normalitas dengan SPSS dapat dilihat bahwa dengan taraf uji sebesar 5\% $(\alpha=0,05)$ semua variabel memiliki $\mathrm{P}$ value (sig.) di atas 0,05 sehingga dapat disimpulkan bahwa semua variabel berdistribusi normal sehingga memenuhi syarat dilakukan metode statistik parametrik analisis regresi linear berganda.

\section{Uji Lineraritas}

Uji linearitas bertujuan untuk mengetahui apakah dua variabel mempunyai hubungan yang linear atau tidak secara signifikan. Uji linearitas biasanya digunakan sebagai prasyarat dalam analisis korelasi atau regresi linear.

Uji liniearitas dilakukan dilakukan dengan mencari persamaan garis regresi variabel pengembangan karier $\left(\mathrm{X}_{1}\right)$ dan beban kerja $\left(\mathrm{X}_{2}\right)$ terhadap kepuasan kerja (Y).

\section{Tabel 7. Hasil Uji Linearitas Antara Variabel Pengembangan Karier dengan Variabel Kepuasan Kerja}

\begin{tabular}{|c|c|c|c|c|c|c|c|}
\hline \multicolumn{8}{|c|}{ ANOVA Table } \\
\hline & & & $\begin{array}{l}\text { Sum of } \\
\text { Squares }\end{array}$ & df & $\begin{array}{l}\text { Mean } \\
\text { Square }\end{array}$ & $\mathrm{F}$ & Sig. \\
\hline KepuasanKerja * & Between & (Combined) & 1331.357 & 22 & 60.516 & 3.913 & .000 \\
\hline PengembanganKarir & Groups & Linearity & 891.112 & 1 & 891.112 & 57.622 & .000 \\
\hline & & Deviation from & 440.246 & 21 & 20.964 & 1.356 & .178 \\
\hline
\end{tabular}




\begin{tabular}{lrrr}
\multicolumn{1}{c}{ Linearity } & & & \\
Within Groups & 943.345 & 61 & 15.465 \\
Total & 2274.702 & 83 & \\
\hline
\end{tabular}

Sumber: Perhitungan SPSS 22.0, 2016

Berdasarkan hasil uji linieritas antara variabel pengembangan karier dengan variabel kepuasan kerja pada Tabel 7 diatas, diketahui bahwa nilai signifikansi linearity sebesar 0.000. Artinya, nilai signifikansi tersebut kurang dari 0,05 sehingga dapat disimpulkan bahwa antara kedua variabel tersebut terdapat hubungan yang linear

Tabel 8. Hasil Uji Linearitas Antara Variabel Beban Kerja dengan Variabel Kepuasan Kerja

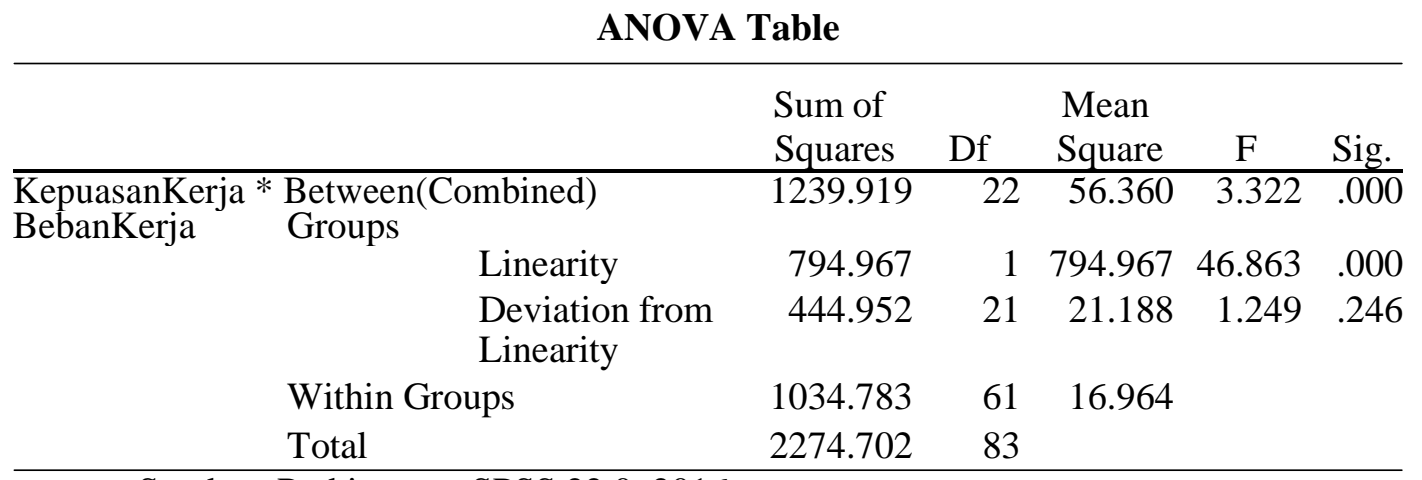

Sumber: Perhitungan SPSS 22.0, 2016

Berdasarkan hasil uji linieritas antara variabel komitmen karyawan dengan variabel kepuasan kerja pada Tabel 8 diatas, diketahui bahwa nilai signifikansi linearity sebesar 0.000. Artinya, nilai signifikansi tersebut kurang dari 0,05 sehingga dapat disimpulkan bahwa antara kedua variabel tersebut terdapat hubungan yang linear.

\section{Uji Multikolinearitas}

Uji multikolinearitas berguna untuk mengetahui apakah pada model regresi yang diajukan telah ditemukan korelasi kuat antar variabel bebas (independen). Mengukur multikoliniearitas dapat diketahui dengan melihat nilai Variance Inflation Factor (VIF) pada model regresi. Jika besar VIF $<5$ atau mendekati 1, maka mencerminkan tidak ada multikolinieritas 
Tabel 9. Hasil Uji Multikolinearitas

\begin{tabular}{llrc}
\multicolumn{4}{c}{ Coefficients $^{\mathbf{a}}$} \\
\hline Model & \multicolumn{3}{c}{ Collinearity Statistics } \\
\cline { 2 - 4 } & & Tolerance & VIF \\
\hline $1 \quad$ & .783 & 1.277 \\
& PengembanganKarir & .783 & 1.277 \\
\hline & BebanKerja & & \\
\hline & a. Dependent Variable: KepuasanKerja & \\
Sumber: Perhitungan SPSS 22.0, 2016 &
\end{tabular}

Berdasarkan hasil uji multikolinearitas pada Tabel 9 dengan menggunakan statistik pengolahan data, diketahui angka VIF untuk pegnembangan karier dan beban kerja yaitu masing-masing sebesar 1.277. Nilai VIF dari seluruh variabel bebas adalah kurang dari 5, maka di antara kedua variabel bebas tersebut tidak ditemukan adanya masalah multikolinearitas.

\section{Uji Heteroskedastisitas}

Heterokedastisitas adalah keadaan di mana terjadi ketidaksamaan varian dari residual untuk semua pengamatan pada model regresi. Jika signifikansi kurang dari 0.05, maka terjadi masalah heteroskedastisitas. Metode yang digunakan dalam penelitian ini adalah metode uji Spearman's Rho, yaitu mengkorelasikan nilai residual (unstandardized residual) dengan masing-masing variabel independen.

\section{Tabel 10. Hasil Uji Heterokedastisitas}

\begin{tabular}{|c|c|c|c|c|c|}
\hline \multicolumn{6}{|c|}{ Correlations } \\
\hline & & & $\begin{array}{l}\text { Unstandardized } \\
\text { Residual }\end{array}$ & PengembanganKarir & BebanKerja \\
\hline \multirow{10}{*}{$\begin{array}{l}\text { Spearman's } \\
\text { rho }\end{array}$} & Unstandardized & Correlation & 1.000 & .032 & -.013 \\
\hline & Residual & Coefficient & & & \\
\hline & & $\begin{array}{l}\text { Sig. (2- } \\
\text { tailed) }\end{array}$ & . & .776 & .906 \\
\hline & & $\mathrm{N}$ & 84 & 84 & 84 \\
\hline & PengembanganKarir & $\begin{array}{l}\text { Correlation } \\
\text { Coefficient }\end{array}$ & .032 & 1.000 & -.498 \\
\hline & & $\begin{array}{l}\text { Sig. }(2- \\
\text { tailed })\end{array}$ & .776 & . & .000 \\
\hline & & $\mathrm{N}$ & 84 & 84 & 84 \\
\hline & BebanKerja & $\begin{array}{l}\text { Correlation } \\
\text { Coefficient }\end{array}$ & -.013 & -.498 & 1.000 \\
\hline & & $\begin{array}{l}\text { Sig. (2- } \\
\text { tailed) }\end{array}$ & .906 & .000 & . \\
\hline & & $\mathrm{N}$ & 84 & 84 & 84 \\
\hline
\end{tabular}


Pada Tabel 10, diketahui korelasi antara pengmebangan karier dengan unstandardizedresidual menghasilkan nilai signifikasi 0,776 ; korelasi antarabeban kerja dengan unstandardized residual menghasilkan nilai 0.906. Jadi, dapat disimpulkan bahwa pada model regresi tidak ditemukan adanya masalah heterokedastisitas hal ini karena nilai signifikansi korelasi lebih besar dari 0.05 .

\section{Uji Hipotesis}

\section{Hasil Persamaan Regresi Linear Sederhana}

Analisis regresi adalah teknik statistika yang berguna untuk memeriksa hubungan di antara variabel-variabel. Penelitian ini menggunakan analisis regresi linear sederhana (simple linear regression). Analisis regresi linear sederhana adalah hubungan secara linear antara satu variabel bebas dengan variabel terikat. Model regresi linear sederhana adalah sebagai berikut:

$$
\mathbf{Y}=\mathbf{a}+\mathbf{b}_{\mathbf{n}} \mathbf{X} \mathbf{n}
$$

$$
\begin{aligned}
& \text { Keterangan: } \\
& \mathrm{Y} \quad=\text { variabel terikat (Kepuasan Kerja) } \\
& \begin{array}{ll}
\mathrm{a}, \mathrm{bn} \quad=\text { parameter } \\
\mathrm{Xn} \quad=\text { variabel bebas }
\end{array}
\end{aligned}
$$

\begin{tabular}{|c|c|c|c|c|c|c|}
\hline \multirow{2}{*}{\multicolumn{2}{|c|}{ Model }} & \multicolumn{2}{|c|}{$\begin{array}{l}\text { Unstandardized } \\
\text { Coefficients }\end{array}$} & \multicolumn{3}{|l|}{$\begin{array}{c}\text { Standardized } \\
\text { Coefficients }\end{array}$} \\
\hline & & $\mathrm{B}$ & Std. Error & Beta & $\mathrm{T}$ & Sig. \\
\hline \multirow[t]{2}{*}{1} & (Constant) & 11.900 & 1.999 & & 5.952 & .000 \\
\hline & PengembanganKarir & .612 & .084 & .626 & 7.267 & .000 \\
\hline
\end{tabular}

Tabel 11. Hasil Persamaan Regresi Linear Sederhana

Coefficients $^{\mathbf{a}}$

Sumber: data diolah oleh peneliti, 2016 
Hipotesis $1\left(\mathrm{H}_{1}\right)$

Ho : Pengembangan karier tidak berpengaruh terhadap kepuasan kerja karyawan

Ha : Pengembangan karier berpengaruh terhadap kepuasan kerja karyawan

Berdasarkan tabel di atas, variabel pengembangan karier memiliki thitung sebesar 7.267. Nilai thitungkemudian dibandingkan dengan nilai tabel yang dicari pada $\alpha=5 \%: 2=2,5 \%$ (uji 2 sisi) dengan derajat kebebasan (df) n-k-1 atau 84-21. Berdasarkan perhitungan tersebut, didapat ttabel sebesar 1.989 dengan demikian thitung $(7.267)>$ tabel $(1.989)$ serta nilai signifikansi $0.000<0.05$. Kesimpulan yang dapat diambil dari hipotesis 1 adalah $\mathrm{H}_{0}$ ditolak dan $\mathrm{H}_{\mathrm{a}}$ diterima.

Berdasarkan Tabel 11.juga dapat diperoleh persamaan regresi linear sederhana untuk hipotesis pertama seperti berikut ini:

$$
\mathrm{Y}=11.900+0.612 \mathrm{X}_{1}
$$

Konstanta pada model persamaan tersebut sebesar 11.900, hal ini berarti tanpa adanya variabel independen pengembangan karier, kepuasan kerja sudah mencapai 11.900. Selanjutnya, variabel pengembangan karier (X1) sebesar 0.612 yang artinya apabila variabel pengembangan karier ditingkatkan sebesar satu satuan, maka variabel kepuasan kerja (Y) akan mengalami kenaikan sebesar 0.612 satuan. Karena koefisien variabel X1 bernilai positif, artinya terjadi pengaruh positif antara pengembangan karier dengan kepuasan kerja. Jika pengembangan karier meningkat maka kepuasan kerja akan meningkat. Begitu juga sebaliknya jika pengembangan karier menurun, maka kepuasan kerja juga akan menurun.

Tabel 12. Hasil Persamaan Regresi Linear Sederhana

\begin{tabular}{|c|c|c|c|c|c|c|}
\hline \multicolumn{7}{|c|}{ Coefficients $^{\mathrm{a}}$} \\
\hline \multirow{2}{*}{\multicolumn{2}{|c|}{ Model }} & \multicolumn{2}{|c|}{ Unstandardized Coefficients } & \multicolumn{3}{|l|}{$\begin{array}{l}\text { Standardized } \\
\text { Coefficients }\end{array}$} \\
\hline & & B & Std. Error & Beta & $\mathrm{t}$ & Sig. \\
\hline \multirow[t]{2}{*}{1} & (Constant) & 40.514 & 2.227 & & 18.196 & .000 \\
\hline & BebanKerja & -.568 & .086 & -.591 & -6.637 & .000 \\
\hline
\end{tabular}


Hipotesis $2\left(\mathrm{H}_{2}\right)$

Ho : Beban kerja tidak berpengaruh terhadap kepuasan kerja karyawan

Ha : Beban kerja berpengaruh terhadap kepuasan kerja karyawan

Berdasarkan tabel di atas, variabel beban kerja memiliki thitung sebesar 6.637. Nilai thitung kemudian dibandingkan dengan nilai tabel yang dicari pada $\alpha=$ $5 \%: 2=2,5 \%$ (uji 2 sisi) dengan derajat kebebasan (df) n-k-1 atau 84-2-1. Berdasarkan perhitungan tersebut, didapat tabel sebesar 1.989 dengan demikian thitung $(-6.637)<$ tabel $(1.989)$ serta nilai signifikansi $0.000<0.005$. Kesimpulan yang dapat diambil dari hipotesis 2 adalah $\mathrm{H}_{0}$ ditolak dan $\mathrm{H}_{\mathrm{a}}$ diterima. Dengan demikian variabel beban kerja memiliki pengaruh negatifdan signifikan terhadap kepuasan kerja. Hal ini sesuai dengan penelitian yang dilakukan oleh Agus Dwi Nugroho, Kunartinah (2012), Sobia Shujaat (2013), dan Nurita Sari (2012). Menurut Veitzhal Rivai (2011:208) pengembangan karier merupakan hal yang penting dimana manajemen dapat meningkatkan produktivitas, meningkatkan sikap karyawan terhadap pekerjaannya, dan membangun kepuasan kerja yang lebih tinggi.

Berdasarkan Tabel 12. juga dapat diperoleh persamaan regresi linearberganda untuk hipotesis ketiga seperti berikut ini:

$$
\mathrm{Y}=40.514+-0.568 \mathrm{X}_{2}
$$

Konstanta pada model persamaan tersebut sebesar 40.514, hal ini berartitanpa adanya variabel independen beban kerja, kepuasan kerja sudah mencapai 40.514. Selanjutnya, koefisien regresi variabel beban kerja (X2) sebesar 0.568. Artinya, jika nilai variabel beban kerja (X2) ditingkatkan sebesar satu satuan, maka variabel kepuasan kerja (Y) akan mengalami kenaikan sebesar0.568. Karena koefisien variabel X2 bernilai negatif, artinya terjadi pengaruh negatif antara beban kerja dengan kepuasan kerja. Jika beban kerja meningkat maka kepuasan kerja akan menurun. Begitu pula sebaliknya, jika beban kerja menurun maka kepuasan kerja akan meningkat. 
Tabel 13. Hasil Uji F (ANOVA) Variabel Independen Pengembangan Karier dan Beban Kerja terhadap Variabel Dependen Kepuasan Kerja

\begin{tabular}{rlrrrrr}
\multicolumn{7}{c}{ ANOVA $^{\mathbf{b}}$} \\
\hline Model & \multicolumn{1}{c}{ Sum of Squares } & Df & Mean Square & \multicolumn{1}{c}{ F } & Sig. \\
\hline \multirow{2}{*}{1} & Regression & 1152.130 & 2 & 576.065 & 41.566 & $.000^{\mathrm{a}}$ \\
& Residual & 1122.572 & 81 & 13.859 & & \\
& Total & 2274.702 & 83 & & & \\
\hline
\end{tabular}

a. Predictors: (Constant), BebanKerja, PengembanganKarir

b. Dependent Variable: KepuasanKerja

Sumber: data diolah oleh peneliti, 2016

Hipotesis $3\left(\mathrm{H}_{3}\right)$

Ho : Pengembangan karier dan beban kerja tidak berpengaruh secara bersama sama terhadap kepuasan kerja karyawan

Ha : Pengembangan karier dan beban kerja berpengaruh secara bersama sama terhadap kepuasan kerja karyawan.

Pada tabel di atas, diketahui bahwa Fhitung yang diperoleh sebesar 41.566. Nilai Fhitung kemudian dibandingkan dengan nilai Ftabel, yang dicari dengan tingkat keyakinan 95\% atau $\alpha=5 \%$, dengan df 1 (jumlah variabel-1) atau 3-1 = 2 , dan df $2(n-k-1)$ atau $84-2-1=81$. Berdasarkan perhitungan tersebut, didapat Ftabel sebesar 3.109 dengan demikian Fhitung(41.566) > Ftabel(3.109). Signifikasi pada uji F sebesar 0,000; dengan demikian lebih kecil dari 0,05. Kesimpulan yang dapat diambil adalah variabel pengembangan karier dan beban kerja berpengaruh secara bersama-sama terhadap variabel kepuasan kerja. Hasil ini sesuai dengan beberapa penelitian terdahulu seperti Sobia Ali and Yasir Aftab Farooqi (2014), Noorani Mustapha (2013) dan Putu Melati Purbaningrat Yo dan Ida Bagus Ketut Surya (2015). Menurut Dhania (2010:16) beban kerja adalah hubungan yang dirasakan antara jumlah kemampuan mental dalam pemrosesan dan jumlah yang dibutuhkan untuk mengerjakan suatu tugas.

Berdasarkan Tabel 13 juga dapat diperoleh persamaan regresi linear berganda untuk hipotesis ketiga seperti berikut ini:

$$
Y^{\prime}=25.289+0.437 \mathrm{X} 1+-0.368 \mathrm{X} 2
$$


Persamaan ini digunakan untuk memprediksi nilai dari variabel dependen apabila nilai variabel independen mengalami kenaikan atau penurunan konstanta pada model persamaan tersebut sebesar 25.289. Hal ini berarti tanpa adanya variabel independen, kepuasan kerja sudah mencapai 25.289. Selanjutnya, koefisien regresi pengembangan karier sebesar 0.437 dan bertanda positif. Hal ini menunjukkan setiap kenaikan nilai variabel pengembangan karier (X1) ditingkatkan sebesar satu satuan dengan asumsi nilai variabel lain tetap, maka variabel kepuasan kerja (Y) akan mengalami kenaikan sebesar 0.437, dan pengembangan karier berpengaruh positif terhadap kepuasan kerja karyawan.

Kemudian koefisien regresi variabel beban kerja (X2) sebesar -0.368 dan bertanda negatif. Hal ini berarti setiap kenaikan nilai variabel beban kerja (X2) ditingkatkan sebesar satu satuan dengan asumsi nilai variabel lain tetap, maka variabel kepuasan kerja (Y) akan mengalami penurunan sebesar -0.368 , dan beban kerja berpengaruh negatif terhadap kepuasan kerja.

\section{Analisis Koefisien Determinasi}

Analisis determinasi dalam regresi linear berganda digunakan untukmengukur seberapa jauh kemampuan model dalam menerangkan variasivariabel terikat.

\section{Tabel 14. Hasil Analisis Determinasi}

\begin{tabular}{|c|c|c|c|c|}
\hline \multicolumn{5}{|c|}{ Model Summary } \\
\hline Model & & & Adjusted R & Std. Error of the \\
\hline & $\mathrm{R}$ & R Square & Square & Estimate \\
\hline 1 & $.712^{\mathrm{a}}$ & .506 & .494 & 3.723 \\
\hline
\end{tabular}

Sumber: Perhitungan SPSS 22.0, 2016

Berdasarkan table 4.23 di atas dapat diketahui bahwa nilai $\mathrm{R}^{2}$ sebesar 0.506 atau (50.6\%).

Hal ini menunjukkan bahwa 50.6\% kepuasan kerja dapat dijelaskan oleh variable pengembangan karier dan beban kerja, sedangkan sisanya sebesar $49.4 \%$ dapat dipengaruhi atau dijelaskan oleh variable lain. 


\section{KESIMPULAN DAN SARAN}

\section{Kesimpulan}

Berdasarkan hasil penelitian, maka menghasilkan kesimpulan sebagai berikut:

1. Pengembangan karier mempunyai pengaruh positif dan signifikan terhadap kepuasan kerja pada karyawan PT Askrindo Jakarta.

2. Beban kerja mempunyai pengaruh negatif dan signifikan terhadap kepuasan kerja pada karyawan PT Askrindo Jakarta.

3. Pengembangan karier dan beban kerja secara bersama sama berpengaruh terhadap kepuasan kerja karyawan PT Askrindo Jakarta.

\section{Saran}

Berdasarkan kesimpulan di atas, beberapa saran yang diajukan dalam penelitian adalah sebagai berikut:

Perusahaan disarankan memberikan frekuensi pelatihan yang sesuai agar karyawan mampu menyelesaikan tugas kerja dengan baik, kemudian memberikan tanggung jawab pekerjaan yang tidak terlampau tinggi kepada karyawan serta perusahaan disarankan memberikan peluang yang sama pada setiap karyawan untuk mendapatkan promosi.

\section{DAFTAR PUSTAKA}

Priyatno, Duwi. 2010.Teknik Mudah dan Cepat Melakukan Analisis DataPenelitian dengan SPSS dan Tanya Jawab Ujian Pendadaran. Yogyakarta:Gaya Media

Hasibuan, Malayu. 2012. Manajemen Sumber Daya Manusia. Jakarta: PT Toko Gunung Agung

Kuncoro, M. 2013. Metode Riset untuk Bisnis dan Ekonomi. Jakarta:Erlangga.

Mangkunegara, Anwar Prabu. 2009. Manajemen Sumber Daya ManusiaPerusahaan. Bandung: PT. Remaja Rosdakarya

Robbins, Stephen P dan Timothy A. Judge. 2008.Perilaku Organisasi,Edisi 12 Buku 1. Jakarta: Salemba Empat.

Rivai, Veithzal. 2011. Manajemen Sumber Daya Manusia Untuk Perusahaan. Jakarta: Grafindo Persada

Wexley, Kenneth N dan Gary A. Yukl. 2012. Perilaku Organisasi Dan PsikologiPerusahaan, Alih Bahasa: M. Shobarudin. Jakarta : Rineka Cipta. 